\title{
Take-home naloxone
}

\author{
Thara Kumar BMSc MD, Hans Rosenberg BSc MD
}

Cite as: CMAJ 2017 September 18;189:E1192. doi: 10.1503/cmaj.170600

CMAJ Podcasts: author interview at https://soundcloud.com/cmajpodcasts/170600-five

1 Naloxone is available without prescription in Canada

In 2016, naloxone was removed from the federal Prescription Drug List, and the National Association of Pharmacy Regulatory Authorities reclassified the drug as Schedule II, meaning pharmacists can dispense it without prescription. ${ }^{1,2}$ It is available in commercial formulations, including intranasal preparations, as well as in locally prepared take-home naloxone kits, available from some pharmacies, clinics, emergency departments and community health centres.

2 Most take-home naloxone kits contain similar equipment Most take-home naloxone kits will contain two ampules of naloxone (0.4 mg per vial), two safety-engineered syringes, two ampule-opening devices, alcohol swabs, nonlatex gloves and a rescue breathing barrier. The average cost for a take-home naloxone kit is $\$ 35$. However, many sites offer them free of charge. ${ }^{1}$

\section{3}

\section{Multiple doses of naloxone may be required for overdoses related to high-potency opioids}

In overdoses related to fentanyl, carfentanil and other synthetic opioids, multiple doses may be required to restore respiration. Most take-home naloxone kits include two doses, and additional doses can safely be administered every two to five minutes if there is no response. ${ }^{3}$ Naloxone should be used in conjunction with basic life support principles, such as rescue breathing, cardiopulmonary resuscitation and calling 911.

Take-home naloxone kits may reduce overdose-related mortality

Although there are limited data on this relatively new intervention, a systematic review published in 2016 looked at 22 observational studies in North America, Europe and Australia, and found that take-home naloxone programs led to improved survival rates among program participants. ${ }^{4}$

\section{Take-home naloxone kits are not only for patients with current opioid abuse}

Other at-risk populations include individuals who are on methadone or on high doses of prescription opioids, or who frequently use recreational drugs. Health practitioners can suggest take-home naloxone to family members and friends of at-risk individuals. ${ }^{5}$ Education and counselling regarding opioid use and abuse is an essential part of the distribution of take-home naloxone.

\section{References}

1. CCENDU Bulletin: The availability of take-home naloxone in Canada. Ottawa: Canadian Centre on Substance Abuse; 2016. Available: www.ccsa.ca/Resource\%20Library/CCSA-CCENDU-Take -Home-Naloxone-Canada-2016-en.pdf (accessed 2017 July 20).

2. National drug schedules: Final recommendation on naloxone hydrochloride. Ottawa: National Association of Pharmacy Regulatory Authorities; 2016. Available: http://napra.ca/ pages/home/default.aspx?id=3758 (accessed 2017 Apr. 4).

3. Naloxone for treatment of opioid overdose. Silver Spring (MD): US Food and Drug Administration; 2016 Oct. 5. Available: www. fda.gov/downloads/AdvisoryCommittees/CommitteesMeeting Materials/Drugs/AnestheticAndAnalgesicDrugProductsAdvisory Committee/UCM522690.pdf (accessed 2017 July 20).

4. McDonald R, Strang J. Are take-home naloxone programmes effective? Systematic review utilizing application of the Bradford Hill criteria. Addiction 2016;111:1177-87.

5. Briefing note: Cost coverage of naloxone and take-home naloxone kits. Ottawa: Canadian Centre on Substance Abuse; 2016. Available: www.ccsa.ca/Resource\%20Library/CCSA-Cost -Coverage-Naloxone-Tool-2016-en.pdf (accessed 2017 Mar. 3).

\section{Competing interests: None declared.}

This article has been peer reviewed.

Affiliation: Department of Emergency Medicine, University of Ottawa/The Ottawa Hospital, Ottawa, Ont.

Contributors: Both authors contributed to the conception of the work and reviewed all drafts and revisions. Both authors give final approval of the version to be published and agree to be accountable for all aspects of the work.

Correspondence to: Hans Rosenberg, hrosenberg33@gmail.com 